\title{
DETERMINAN STRUKTUR MODAL PERUSAHAAN INFRASTRUKTUR, UTILITAS, DAN TRANSPORTASI
}

\author{
Arini Dwi Febriani ${ }^{1}$ \\ Farida Titik Kristanti ${ }^{2}$
}

\author{
Fakultas Ekonomi dan Bisnis Universitas Telkom, Jawa Barat, Indonesia ${ }^{1,2}$ \\ Email: arini1202@gmail.com / Telp:082216441833
}

\begin{abstract}
The tight competition in the era of globalization requires companies to be able to maximize its value in order to remain competitive with other companies. Decision in the formation of capital structure is one of the important decisions that can maximize the value of the company. When the process of forming an optimal capital structure, it is important for financial managers to pay attention to the determinants of the capital structure. This study aims to investigate the factors that determine the capital structure in the infrastructure, utilities, and transportation companies. Several factors investigated for its effect on capital structure are profitability, company growth, company size, assets structure, non-debt tax shield, and business risk. Purposive sampling is a method used in research sampling, in which 216 research samples were obtained consisting of 36 companies with a 6 years study period, namely 2013-2018. The panel data regression model is used as a model to investigate the determinants of capital structure. The results show that the company growth and the company size negatively affected the capital structure, while profitability, asset structure, nondebt tax shield, and business risk did not affect the capital structure.
\end{abstract}

Keywords: Capital Structure; Determinants; Panel Data Regression.

\begin{abstract}
ABSTRAK
Ketatnya persaingan usaha pada era globalisasi menuntut perusahaan untuk mampu memaksimalkan nilainya agar tetap dapat bersaing dengan perusahaan lainnya. Keputusan dalam pembentukan struktur modal adalah salah satu keputusan penting yang dapat memaksimalkan nilai perusahaan. Pada saat proses pembentukan struktur modal yang optimal, penting bagi manajer keuangan untuk memerhatikan determinan dari struktur modal. Penelitian ini bertujuan untuk menyelidiki determinan struktur modal pada perusahaan sektor infrastruktur, utilitas, dan transportasi. Beberapa faktor yang diselidiki pengaruhnya pada struktur modal adalah profitabilitas, pertumbuhan perusahaan, ukuran perusahaan, struktur aset, non-debt tax shield, dan risiko bisnis. Purposive sampling merupakan metode yang diterapkan dalam pengambilan sampel penelitian, di mana diperoleh sejumlah 216 sampel penelitian yang terdiri atas 36 perusahaan dengan 6 tahun periode penelitian, yaitu tahun 2013-2018. Model regresi data panel digunakan sebagai model untuk menyelidiki determinan struktur modal. Hasil penelitian mengungkapkan bahwa pertumbuhan perusahaan dan ukuran perusahaan masing-masing secara negatif signifikan memengaruhi struktur modal, sedangkan profitabilitas, struktur aset, non-debt tax shield, dan risiko bisnis masing-masing tidak memengaruhi struktur modal.
\end{abstract}

Kata kunci: Struktur Modal; Determinan; Regresi Data Panel. 


\section{PENDAHULUAN}

Ketatnya persaingan usaha pada era globalisasi menuntut perusahaan untuk mampu memaksimalkan nilainya agar tetap dapat bersaing dengan perusahaan lainnya. Nilai perusahaan yang maksimal dapat dicapai ketika manajer keuangan menentukan keputusan keuangannya dengan tepat. Keputusan pendanaan yang tepat akan meningkatkan laba perusahaan dan akhirnya nilai perusahaan akan meningkat. Studi Kristanti \& Iswandi (2019) menunjukkan bahwa struktur modal perusahaan mempengaruhi kinerjanya.

Salah satu jenis keputusan keuangan adalah keputusan pendanaan atau keputusan atas pemilihan sumber dana yang hendak digunakan dalam aktivitas operasi perusahaan. Keputusan pendanaan juga disebut sebagai pembentukan struktur modal. Pengertian dari struktur modal menurut Musthafa (2017:85), yaitu perbandingan antara jumlah modal asing atau jumlah modal yang berasal dari hutang dengan jumlah modal sendiri. Fahmi (2018:184), mendefinisikan struktur modal sebagai suatu cerminan bentuk proporsi finansial yang digunakan sebagai sumber pembiayaan suatu perusahaan. Proporsi finansial tersebut terdiri dari modal asing yang bersumber dari utang jangka panjang dan modal yang bersumber dari internal perusahaan atau modal sendiri.

Teori Trade-off dan Teori Pecking Order merupakan beberapa teori yang dapat melandasi struktur modal. Menurut Sulindawati et al. (2017:115), pada teori trade-off, beberapa faktor dimasukkan guna menghasilkan bentuk struktur modal optimal dengan asumsi bahwa efisiensi pasar dan dan informasi yang simetris 
adalah imbangan dan keuntungan dari penggunaan utang. Beberapa faktor tersebut adalah pajak, biaya keagenan, dan biaya financial distress.Teori ini pun mengutarakan bahwa perusahaan dikatakan telah mencapai tingkat utang yang optimal ketika jumlah penghematan pajak terhadap biaya kesulitan keuangannya telah mencapai jumlah yang maksimal.

Menurut Mulyawan (2015:250-251), teori Pecking Order yang dikembangkan oleh Stewart Myers (1984) menyatakan bahwa perusahaan mengutamakan sumber pendanaan internal, yaitu laba ditahan dan nilai penyusutan. Apabila memerlukan pendanaan dari eksternal, pertama-tama perusahaan akan memutuskan untuk menggunakan sumber pendanaan saham yang dirasa paling aman terlebih dahulu. Jika pendanaan dari luar dibutuhkan lebih banyak lagi, maka perusahaan akan memilih pemakaian utang yang aman, lalu yang memiliki risiko, dan terakhir adalah melalui saham umum. Asumsi lainnya yang mendasari teori ini adalah kebijakan dividen merupakan kebijakan yang kaku, sehingga pihak manajemen akan selalu menjaga kestabilan tingkat pembayaran dividen.

Objek yang digunakan pada penelitian ini adalah sektor infrastruktur, utilitas, dan transportasi yang terdaftar di BEI pada periode 2013-2018. Sektor infrastruktur, utilitas, dan transportasi yang termasuk kedalam industri jasa merupakan salah satu sektor penyumbang kapitalisasi pasar tertinggi di BEI. Akan tetapi menurut data statistik tahunan BEI, nilai struktur modal pada perusahaan sektor infrastruktur, utilitas, dan transportasi cenderung menurun dalam enam tahun terakhir. 
Nilai struktur modal yang pengukurannya menggunakan rasio utang terhadap ekuitas (DER) pada tahun 2013 adalah sebesar 3,07. Penurunan yang drastis terjadi di 2014, dimana nilainya menjadi 0,71. Pada 2015 dan 2016, terjadi peningkatan nilai struktur modal yaitu menjadi 1,23 dan 2,49. Namun, di tahun 2017 dan 2018, nilai struktur modal mengalami penurunan menjadi 1,36 dan 0,71. Nilai struktur modal yang relatif menurun setiap tahunnya menandakan bahwa penggunaan modal sendiri pada perusahaan sektor infrastruktur, utilitas, dan transportasi meningkat dan penggunaan modal sendiri lebih dominan dibandingkan dengan pengunaan modal asing atau utang.

Proporsi struktur modal yang lebih dominan menggunakan modal sendiri belum tentu dapat menghasilkan struktur modal yang optimal. Perusahaan yang penggunaan modal sendirinya lebih banyak akan memiliki jumlah dana yang terbatas, sedangkan dana atau modal sangat dibutuhkan untuk pertumbuhan perusahaan. Penggunaan modal sendiri juga akan menyebabkan timbulnya opportunity cost (Kaliman \& Wibowo, 2017). Menurut Aisjah (2012:45), penggunaan modal sendiri yang lebih dominan juga akan menurunkan nilai perusahaan, karena ketika saham baru diterbitkan para investor akan menganggap hal tersebut sebagai sinyal buruk yang akan mengakibatkan harga saham menurun, biaya modal sendiri meningkat, dan akhirnya nilai perusahaan akan cenderung menurun. Modigliani dan Miller menyatakan bahwa penggunaan utang kerap lebih memberikan keuntungan dibandingkan dengan menggunakan modal sendiri karena pihak perbankan akan menetapkan bunga berdasarkan kondisi perekonomian negara yang kemungkinan tidak akan memberatkan para debitur (Fahmi, 
2018:194).

Peran manajer keuangan sangat penting dalam memutuskan bentuk struktur modal yang optimal bagi perusahaan, karena apabila keputusan yang diambil oleh manajer keuangan tidak tepat, maka akan mengakibatkan turunnya nilai perusahaan bahkan akan menyebabkan kebangkrutan. Pada saat proses pembentukan struktur modal yang optimal, penting bagi manajer keuangan untuk memerhatikan determinan dari struktur modal. Beberapa faktor yang diduga dapat menjadi penentu struktur modal adalah profitabilitas, pertumbuhan perusahaan, ukuran perusahaan, struktur aset, non-debt tax shield, dan risiko bisnis.

Penelitian terdahulu yang meneliti profitabilitas pada struktur modal adalah penelitian Dewi et al. (2017) yang menemukan bahwa profitabilitas secara positif signifikan memengaruhi struktur modal. Berlainan dengan Kyissima et al. (2019), Dewiningrat \& Mustanda (2018), Dewi et al. (2017), Kaliman \& Wibowo (2017), Sofat \& Singh (2017), Antoni et al. (2016), Pratheepan \& Banda, (2016), Acaravci (2015), Alipour et al. (2015), Alnajjar (2015), Chadha \& Sharma (2015), dan Sumani (2015) yang membuktikan adanya pengaruh negatif dan signifikan. Sedangkan penelitian Widayanti et al. (2016) menemukan bahwa tidak terdapat hubungan yang signifikan antara profitabilitas dan struktur modal.

Penelitian terdahulu yang meneliti pertumbuhan perusahaan pada struktur modal adalah penelitian Pratheepan \& Banda (2016), Acaravci (2015), Alnajjar (2015), dan Sawitri \& Lestari (2015) yang menunjukkan pertumbuhan perusahaan memengaruhi struktur modal secara positif dan signifikan. Berbeda dengan 
Dewiningrat \& Mustanda (2018), Alipour et al. (2015), dan Chadha \& Sharma (2015) yang membuktikan adanya pengaruh secara negatif signifikan. Berbeda juga dengan penelitian Kristanti \& Rahayu (2018), Dewi et al. (2017), Kaliman \& Wibowo (2017), Widayanti et al. (2016), Krisnanda \& Wiksuana (2015), dan Sumani (2015) yang menemukan bahwa tidak terdapat hubungan hubungan yang signifikan antara pertumbuhan perusahaan dan struktur modal.

Penelitian terdahulu yang meneliti ukuran perusahaan pada struktur modal adalah penelitian Kyissima et al. (2019), Kaliman \& Wibowo (2017), Antoni et al. (2016), Pratheepan \& Banda (2016), dan Alnajjar (2015) yang menemukan ukuran perusahaan memengaruhi struktur modal secara positif signifikan. Lain halnya dengan penelitian Kristanti \& Rahayu (2018), Dewi et al. (2017), Acaravci (2015), Alipour et al. (2015), dan Chadha \& Sharma (2015) yang menunjukkan bahwa adanya pengaruh secara negatif signifikan. Sedangkan Sofat \& Singh (2017), Krisnanda \& Wiksuana (2015), Sawitri \& Lestari (2015), dan Sumani (2015) menemukan bahwa tidak terdapat hubungan yang signifikan antara ukuran perusahaan dan struktur modal.

Penelitian terdahulu yang meneliti struktur aset pada struktur modal adalah penelitian Dewiningrat \& Mustanda (2018) dan Sofat \& Singh (2017) yang menemukan bahwa struktur aset memengaruhi struktur modal secara positif signifikan. Berlainan dengan Alipour et al. (2015) yang menemukan pengaruh negatif signifikan. Dewi et al. (2017) dan Sumani (2015) menunjukkan struktur modal tidak dipengaruhi oleh struktur aset. Chadha \& Sharma (2015) menemukan 
hubungan positif signifikan antara tangibility assets dengan struktur modal. Hubungan negatif signifikan ditemukan oleh Acaravci (2015). Sedangkan hasil penelitian Kyissima et al. (2019), dan Pratheepan \& Banda (2016) menemukan tidak adanya pengaruh antara tangibility assets dengan struktur modal.

Penelitian terdahulu yang meneliti NDTS pada struktur modal adalah penelitian penelitian Chadha \& Sharma (2015) dan Krisnanda \& Wiksuana (2015) yang menunjukkan NDTS memengaruhi struktur modal secara positif dan signifikan. Lain halnya dengan Dewi et al. (2017) yang membuktikan bahwa adanya hubungan secara negatif. Hasil penelitian Pratheepan \& Banda (2016) dan Acaravci (2015) adalah NDTS tidak memengaruhi struktur modal.

Penelitian terdahulu yang meneliti tentang hubungan antara risiko bisnis dengan struktur modal adalah penelitian Sofat \& Singh (2017) dan Chadha \& Sharma (2015) menemukan bahwa risiko memengaruhi struktur modal secara positif signifikan. Sedangkan hasil penelitian Alipour et al. (2015), Alnajjar (2015), dan Sumani (2015) menemukan hubungan yang negatif signifikan. Hasil lain ditemukan oleh Dewi et al. (2017), Kaliman \& Wibowo (2017), dan Sawitri \& Lestari (2015), yaitu risiko bisnis tidak memengaruhi struktur modal.

Inkonsistensi atau perbedaan hasil pada penelitian terdahulu menunjukkan bahwa variabel-variabel tersebut masih perlu untuk dikaji pengaruhnya terhadap struktur modal. Penelitian ini bertujuan untuk menyelidiki pengaruh variabel profitabilitas, pertumbuhan perusahaan, ukuran perusahaan, struktur aset, non-debt tax shield, dan risiko bisnis terhadap struktur modal. 
Profitabilitas menurut Hery (2016:192) ialah rasio yang menilai seberapa jauh kemampuan suatu perusahaan dalam mendapatkan keuntungan melalui kemampuan dan sumber daya yang dipunyanya. Tingginya nilai profitabilitas menandakan perusahaan memiliki modal sendiri yang berlimpah. Perusahaan yang memiliki banyak dana internal akan mengutamakan pendanaan internal ketimbang meminjam dari pihak eksternal. sejalan teori pecking order, semakin besar nilai profitabilitas perusahaan, maka tingkat hutangnya semakin rendah karena memiliki modal sendiri yang melimpah. Hasil penelitian yang mendukung adalah Kyissima et al. (2019), Dewiningrat \& Mustanda (2018), Dewi et al. (2017), Kaliman \& Wibowo (2017), Sofat \& Singh (2017), Antoni et al. (2016), Pratheepan \& Banda, (2016), Acaravci (2015), Alipour et al. (2015), Alnajjar (2015), Chadha \& Sharma (2015), dan Sumani (2015).

$\mathrm{H}_{1}$ : Profitabilitas memengaruhi Struktur Modal secara negatif signifikan.

Pertumbuhan perusahaan menurut Fahmi (2018:82) adalah rasio keuangan yang mengestimasi kemampuan perusahaan dalam mempertahankan kedudukannya di tengah perkembangan ekonomi umum dan dalam industrinya. Tingkat pertumbuhan perusahaan yang semakin tinggi akan meningkatkan kebutuhan dana untuk mendukung perkembangannya. Semakin tinggi tingkat pertumbuhan penjualan juga dapat memudahkan perusahaan dalam mendapatkan pinjaman (Sawitri \& Lestari, 2015). Hasil penelitian yang mendukung adalah penelitian Pratheepan \& Banda (2016), Acaravci (2015), Alnajjar (2015), dan Sawitri \& Lestari (2015). 
$\mathrm{H}_{2}$ : Pertumbuhan Perusahaan memengaruhi Struktur Modal secara positif signifikan.

Ukuran Perusahaan adalah cerminan dari kemampuan suatu perusahaan dalam melakukan aktivitas penjualan dan jumlah karyawan yang dimilikinya dan dapat disebut juga sebagai jumlah aset yang dimiliki oleh perusahaan (Sawitri \& Lestari, 2015). Perusahaan yang tergolong sebagai perusahaan besar membutuhkan dana yang lebih besar untuk modalnya dibandingkan dengan yang dibutuhkan oleh perusahaan yang tergolong sebagai perusahaan kecil, maka dari itu perusahaan akan menggunakan lebih banyak hutang. Semakin besar ukurannya, semakin mungkin perusahaan tersebut untuk mendapatkan pinjaman dan memanfaatkan pendanaan jangka panjang dibanding perusahaan kecil. (Kaliman \& Wibowo, 2017). Penelitian yang mendukung adalah penelitian yang diteliti oleh Kyissima et al. (2019), Kaliman \& Wibowo (2017), Antoni et al. (2016), Pratheepan \& Banda (2016), dan Alnajjar (2015).

$\mathrm{H}_{3}$ : Ukuran Perusahaan memengaruhi Struktur Modal secara positif signifikan.

Menurut Riyanto (2010:22), struktur kekayaan atau struktur aset ialah proporsi antara kepemilikan aset lancar dengan aset tetap. Semakin melimpah kepemilikan aset tetapnya, maka perusahaan akan meningkatkan penggunaan utangnya karena aset tersebut dapat dimanfaatkan sebagai agunan atas utang yang akan diambil ketika perusahaan mengalami kesulitan keuangan (Mulyawan, 2015:246). Menurut teori trade off, tangibility atau aset tetap dapat menarik lebih banyak utang dan juga dapat mengurangi financial distress pada perusahaan 
(Acaravci, 2015). Penelitian yang mendukung adalah penelitian Dewiningrat \& Mustanda (2018), Sofat \& Singh (2017), dan Chadha \& Sharma (2015).

$\mathrm{H}_{4}$ : Struktur Aset memengaruhi Struktur Modal secara positif signifikan.

Non-debt tax shield (NDTS) merupakan penghematan pajak yang sumbernya bukan berasal dari beban bunga atas utang yang dimiliki oleh perusahaan (Krisnanda \& Wiksuana, 2015). Acaravci (2015) menyatakan bahwa NDTS dapat ukur dengan rasio depresiasi terhadap total aset. Menurut Krisnanda \& Wiksuana (2015), nilai depresiasi perusahaan yang tinggi menunjukkan bahwa perusahaan memiliki banyak aset tetap, sehingga mempermudah perusahaan dalam mendapatkan pinjaman dengan mengagunkan asetnya. Penelitian yang mendukung adalah penelitian yang diteliti oleh Chadha \& Sharma (2015) dan Krisnanda \& Wiksuana (2015).

$\mathrm{H}_{5}$ : NDTS memengaruhi Struktur Modal secara positif signifikan.

Risiko bisnis menurut Musthafa (2017:86) adalah risiko yang timbul akibat dari perusahaan tidak menggunakan utang dalam kegiatan operasinya. Perusahaan yang tingkat risiko bisnisnya tinggi cenderung memiliki tingkat utang yang rendah, karena jumlah utang yang tinggi akan menyebabkan perusahaan tersebut sulit untuk memenuhi kewajibannya (Sumani, 2015). Perusahaan yang berisiko tinggi akan meminimalkan tingkat utangnya karena akan mengingkatkan risiko perusahaan dan pihak kreditor pun akan sulit untuk memberikan utang ke perusahaan yang tingkat risikonya tinggi (Dewi et al., 2017). Penelitian yang mendukung adalah penelitian 
Alipour et al. (2015), Alnajjar (2015), dan Sumani (2015).

$\mathrm{H}_{6}$ : Risiko Bisnis memengaruhi Struktur Modal secara negatif signifikan.

\section{METODE PENELITIAN}

Objek yang diteliti pada penelitian ini adalah Perusahaan Sektor Infrastruktur, Utilitas, dan Transportasi yang tercatat di Bursa Efek Indonesia (BEI) selama 2013-2018. Data sekunder yang tertera pada laporan tahunan dan ringkasan performa perusahaan merupakan data yang digunakan pada penelitian ini. Purposive sampling merupakan metode yang diterapkan dalam pengambilan sampel penelitian, di mana diperoleh sejumlah 216 sampel penelitian yang terdiri atas 36 perusahaan sektor Infrastruktur, Utilitas, dan Transportasi dalam kurun waktu 6 tahun, yaitu 2013-2018.

Beberapa variabel yang diteliti pada penelitian ini ialah Struktur Modal yang berperan sebagai variabel dependen, dan Profitabilitas, Pertumbuhan Perusahaan, Ukuran Perusahaan, Struktur Aset, Non-Debt Tax Shield, serta Risiko Bisnis yang berperan sebagai variabel independen.

Struktur modal adalah suatu cerminan bentuk proporsi finansial yang digunakan sebagai sumber pembiayaan suatu perusahaan. Proporsi finansial tersebut terdiri dari modal asing yang bersumber dari utang jangka panjang dan modal sendiri Fahmi (2018:184). Menurut Hery (2016:162-169), rasio leverage dapat dijadikan sebagai dasar pertimbangan dalam memutuskan sumber pendaan perusahaan atau pembentukan struktur modal, salah satunya adalah rasio utang 
terhadap ekuitas (DER) yang diukur dengan jumlah utang dibagi dengan jumlah modal.

Profitabilitas menurut Hery (2016:192) ialah rasio yang menilai seberapa jauh kemampuan suatu perusahaan dalam mendapatkan keuntungan melalui kemampuan dan sumber daya yang dipunyanya. Rasio pengembalian atas aset (ROA) yaitu keuntungan bersih dibagi dengan jumlah aset dapat dijadikan sebagai alat untuk mengestimasi nilai profitabilitas.

Pertumbuhan perusahaan menurut Fahmi (2018:82) adalah rasio keuangan yang mengestimasi kemampuan perusahaan dalam mempertahankan kedudukannya di tengah perkembangan ekonomi umum dan dalam industrinya. Pertumbuhan perusahaan dihitung dengan hasil dari selisih pendapatan pada tahun ini dan sebelumnya dibagi dengan jumlah pendapatan tahun sebelumnya.

Ukuran Perusahaan adalah cerminan dari kemampuan suatu perusahaan dalam melakukan aktivitas penjualan dan jumlah karyawan yang dimilikinya dan dapat disebut juga sebagai jumlah aset yang dimiliki oleh perusahaan (Sawitri \& Lestari, 2015). Variabel ukuran perusahaan dihitung dengan logaritma natural dari jumlah aset.

Menurut Riyanto (2010:22), struktur kekayaan atau struktur aset ialah proporsi antara kepemilikan aset lancar dengan aset tetap. Struktur Aset dihitung dengan cara membandingkan aset tetap dengan jumlah aset (Sumani, 2015).

Non-debt tax shield (NDTS) merupakan penghematan pajak yang 
sumbernya bukan berasal dari beban bunga atas utang yang dimiliki oleh perusahaan (Krisnanda \& Wiksuana, 2015). Menurut Acaravci (2015), nilai depresiasi dibagi dengan jumlah aset adalah cara untuk mengukur nilai non-debt tax shield.

Risiko bisnis menurut Musthafa (2017:86) adalah risiko yang timbul akibat dari perusahaan tidak menggunakan utang dalam kegiatan operasinya. Menurut Sulindawati et al. (2017), nilai risiko bisnis dapat dilihat dari nilai operating leverage, atau perubahan keuntungan sebelum bunga dan pajak (EBIT) dibagi dengan perubahan penjualan.

Teknik analisis data yang digunakan adalah analisis kuantitatif dengan metode perhitungan statistik deskriptif. Model regresi data panel digunakan sebagai model untuk menyelidiki determinan struktur modal. Beberapa pendekatan yang dapat dilakukan dalam menguji model regresi data panel menurut Basuki \& Prawoto (2016:276-277) adalah common effect, fixed effect, dan random effect. Uji pemilihan model yang dipakai untuk memutuskan model pendekatan yang tepat pada penelitian adalah uji chow, uji hausman, dan uji lagrange multiple.

Uji asumsi klasik yang diperlukan pada regresi data panel menurut Basuki \& Parwoto (2016:298) adalah uji multikolinearitas dan uji heterokedastisitas. Uji hipotesis dilaksanakan dengan menguji tingkat signifikansi dari pengaruh variabel independen terhadap variabel dependen, baik secara simultan ataupun secara parsial. Besarnya kemampuan variabel independen dalam menerangkan variabel dependen dapat dibuktikan dengan menganalisis hasil dari koefisien determinasi. 


\section{HASIL DAN PEMBAHASAN}

Tabel 1. menyajikan gambaran karakteristik dari data penelitian. Beberapa karakteristik yang disajikan adalah nilai mean, tertinggi, terendah, dan deviasi standar dari setiap variabel penelitian. Nilai tertinggi dari variabel struktur modal adalah sebesar 16,74885 yang terjadi pada PT Trada Alam Minera Tbk di tahun 2016. Penyebab dari timbulnya kondisi tersebut adalah total liabilitas yang dimiliki adalah sebesar Rp2.051.952.849.462,37, sedangkan total ekuitas yang dimiliki sebesar Rp122.513.077.956,99. Nilai terendahnya adalah $-8,988568$ yang terjadi pada PT ICTSI Jasa Prima Tbk di tahun 2013. Penyebab dari timbulnya kondisi tersebut adalah total liabilitas yang dimiliki sebesar Rp772.644.687.500,00, sedangkan total disefisiensi modalnya sebesar -Rp85.958.600.000,00. Nilai deviasi standar variabel sebesar 2,375609 dimana nilai tersebut lebih tinggi dari nilai mean, yaitu 1,525474. Hal ini berarti variabel struktur modal memiliki data yang heterogen atau bervariasi.

Tabel 1.

Hasil Uji Statistik Deskriptif

\begin{tabular}{|c|c|c|c|c|c|c|c|}
\hline & CS & PROF & GROWTH & SIZE & $\mathbf{S A}$ & NDTS & RISK \\
\hline Mean & 1,525474 & 0,003993 & 0,115688 & 29,09723 & 0,556472 & 0,063911 & 5,004333 \\
\hline Maximum & 16,74885 & 1,851710 & 5,733348 & 32,95985 & 0,941803 & 0,366457 & 722,5425 \\
\hline Minimum & $-8,988568$ & $-1,279100$ & $-0,922052$ & 26,42706 & 0,007339 & 0,000976 & $-967,6446$ \\
\hline Deviasi Std. & 2,375609 & 0,193139 & 0,474275 & 1,650723 & 0,283852 & 0,046149 & 98,98334 \\
\hline Observations & 216 & 216 & 216 & 216 & 216 & 216 & 216 \\
\hline
\end{tabular}


Nilai tertinggi variabel profitabilitas adalah 1,851710 dicapai oleh PT Berlian Laju Tanker Tbk di tahun 2015. Penyebab dari timbulnya kondisi tersebut adalah besar laba bersih yang diperoleh adalah Rp2.582.331.034.482,76 sedangkan total asetnya sebesar Rp1.394.565.517.241,38. Nilai terendahnya adalah -1,279100 yaitu dimiliki oleh PT ICTSI Jasa Prima Tbk di tahun 2015 dengan rugi bersih sebesar -Rp405.027.041.666,67 dan total aset sebesar Rp316.649.972.222,22. Nilai deviasi standar variabel profitabilitas sebesar 0,193139, dimana nilainya lebih tinggi dari nilai mean, yaitu 0,003993. Hal ini menunjukkan data variabel profitabilitas bersifat heterogen atau bervariasi.

Nilai tertinggi variabel pertumbuhan perusahaan adalah 5,733348 yang terjadi pada PT Trada Alam Minera Tbk di tahun 2018. Penyebab dari timbulnya kondisi tersebut adalah jumlah penjualan yang dihasilkan pada tahun 2018 sebesar Rp3.482.706.786.000,00 sedangkan pada 2017 adalah Rp517.232.588.000,00. Nilai terendahnya sebesar -0,922052 terjadi pada PT Berlian Laju Tanker Tbk di tahun 2016 dengan jumlah penjualan pada tahun 2015 sebesar Rp3.492.289.655.172,41 dan penjualan pada tahun 2016 sebesar Rp272.217.741.935,48. Nilai deviasi standar variabel pertumbuhan perusahaan adalah 0,474275 , dimana nilainya lebih tinggi dari nilai mean, yaitu 0,071773 . Hal tersebut berarti variabel pertumbuhan perusahaan memiliki data yang heterogen atau bervariasi.

Nilai tertinggi dari variabel ukuran perusahaan terjadi pada PT Telekomunikasi Indonesia (Persero) Tbk di tahun 2018, yaitu 32,95985. Penyebab 
dari timbulnya kondisi tersebut adalah jumlah aset yang dimiliki perusahaan adalah sebesar Rp206.196.000.000.000,00. Nilai terendah terjadi pada PT Weha Transportasi Indonesia Tbk di tahun 2017, yaitu 26,42706. Jumlah aset yang dimiliki perusahaan tersebut adalah Rp300.003.474.668,00. Nilai deviasi standar variabel ukuran perusahaan adalah 1,650723, nilai tersebut lebih rendah dari nilai mean, yaitu 29,09723. Hal tersebut berarti variabel ukuran perusahaan memiliki data yang homogen atau berkelompok.

Nilai tertinggi variabel struktur aset adalah 0,941803 yang terjadi pada PT Pelayaran Nasional Bina Buana Raya Tbk di tahun 2017 Penyebab dari timbulnya kondisi tersebut adalah jumlah aset tetap yang dimiliki perusahaan sebesar Rp1.221.609.413.103,56 dan total aset sebesar Rp1.297.096.095.485,83. Nilai terendah sebesar 0,007339 terjadi pada PT Sarana Menara Nusantara Tbk di tahun 2015. Penyebab dari timbulnya kondisi tersebut adalah aset tetap yang dimiliki perusahaan adalah sebesar Rp157.179.000.000,00, sedangkan total asetnya sebesar Rp21.416.709.000.000,00. Nilai standar deviasi variabel struktur aset sebesar 0,283852. Nilai tersebut lebih rendah dari nilai mean, yaitu 0,556472. Hal tersebut berarti variabel struktur aset memiliki data yang homogen atau berkelompok.

Nilai tertinggi variabel non-debt tax shield sebesar 0,366457 yang dicapai oleh PT Berlian Laju Tanker Tbk di tahun 2015. Penyebab dari timbulnya kondisi tersebut adalah nilai depresiasi yang dimiliki sebesar Rp511.048.275.862,07 sedangkan total aset sebesar Rp1.394.565.517.241,38. Nilai terendah dimiliki oleh 
PT Tower Bersama Infrastructure Tbk pada tahun 2015, yaitu 0,000976 dengan nilai depresiasi sebesar Rp22.258.000.000,00 dan total aset sebesar Rp22.799.671.000.000,00. Nilai deviasi standarnya sebesar 0,046149, dimana lebih rendah dari nilai mean, yaitu 0,063911. Hal tersebut berarti variabel non-debt tax shield memiliki data yang homogen atau berkelompok.

Nilai tertinggi variabel risiko bisnis sebesar 722,5425 terjadi pada PT Weha Transportasi Indonesia Tbk di tahun 2017 dengan perubahan EBIT sebesar $250,72 \%$ dan perubahan penjualan sebesar $0,35 \%$. Nilai terendahnya sebesar 967,6446 yang terjadi pada PT XL Axiata Tbk di tahun 2018. Penyebab dari timbulnya kondisi tersebut adalah rendahnya nilai perubahan EBIT, yaitu -267.13\% sedangkan besar perubahan penjualannya adalah $0.28 \%$. Nilai deviasi standarnya sebesar 98,98334, dimana lebih tinggi dari nilai mean, yaitu 5,004333. Hal tersebut dapat diartikan bahwa variabel risiko bisnis memiliki data yang heterogen atau bervariasi.

Uji asumsi klasik yang diperlukan pada regresi data panel menurut Basuki \& Parwoto (2016:298) adalah uji multikolinearitas dan uji heterokedastisitas. Menurut Ghozali \& Ratmono (2017:73), model regresi yang terbebas dari multikolinearitas adalah yang nilai korelasi antarvariabel independennya lebih rendah dari 0,80. Tabel 2. menunjukkan bahwa nilai korelasi antarvariabel independen relatif rendah dan nilainya kurang dari 0,80. Berdasarkan hasil pengujian, dapat diputuskan bahwa masing-masing variabel independen yang akan diteliti tidak mengalami masalah multikolinearitas. 
Tabel 2.

Hasil Uji Multikolinearitas

\begin{tabular}{ccccccc}
\hline & PROF & GROWTH & SIZE & SA & NDTS & RISK \\
\hline \multirow{2}{*}{ PROF } & 1,000000 & 0,088147 & 0,135021 & $-0,227655$ & 0,122426 & $-0,042681$ \\
GROWTH & 0,088147 & 1,000000 & 0,105047 & $-0,157046$ & $-0,157205$ & $-0,023065$ \\
SIZE & 0,135021 & 0,105047 & 1,000000 & $-0,272692$ & $-0,073463$ & $-0,212027$ \\
SA & $-0,227655$ & $-0,157046$ & $-0,272692$ & 1,000000 & 0,532362 & 0,007839 \\
NDTS & 0,122426 & $-0,157205$ & $-0,073463$ & 0,532362 & 1,000000 & $-0,146166$ \\
RISK & $-0,042681$ & $-0,023065$ & $-0,212027$ & 0,007839 & $-0,146166$ & 1,000000 \\
\hline \multicolumn{2}{c}{ Sumber: data diolah, 2020} & & & & &
\end{tabular}

Menurut (Ghozali \& Ratmono, 2017:91-93), model regresi yang tidak mengalami heterokedastisitas adalah yang nilai Obs*R-squarednya memiliki nilai probabilitas Chi-Square yang tidak signifikan atau lebih tinggi dari 0,05. Tabel 3. Memperlihatkan nilai dari probabilitas Chi-Square yang dimiliki oleh nilai Obs*Rsquared adalah 0,9098, dimana lebih tinggi dari 0,05. Hasil tersebut membuktikan bahwa sebaran data pada model regresi yang akan diteliti bersifat homogen dan tidak mengalami heterokedastisitas.

Tabel 3.

Hasil Uji Heterokedastisitas

\section{Uji Heterokedastisitas: White}

\begin{tabular}{llll} 
F-statistic & 0,342737 & Probabilitas F(6,209) & 0,9135 \\
Obs*R-squared & 2,104590 & Probabilitas Chi-Square(6) & 0,9098 \\
Scaled explained SS & 17,08796 & Probabilitas Chi-Square(6) & 0,0090 \\
\hline Sumber: data diolah, 2020 & &
\end{tabular}


Tiga jenis uji yang dilakukan untuk memutuskan model pendekatan yang sesuai adalah uji chow, uji hausman, dan uji lagrange multiple. Uji chow dilaksanakan guna mengetahui model yang lebih sesuai antara model fixed effect atau model common effect. Uji hausman dilakukan untuk mengetahui model yang lebih sesuai antara model fixed effect atau model random effect. Uji lagrange multiple dilaksanakan untuk mengetahui model yang lebih sesuai antara model random effect atau model common effect.

Tabel 4.

Hasil Uji Chow

\begin{tabular}{lrrr} 
Effect Test & Statistik & d.f. & Prob. \\
Cross-section F & 7,652415 & $(35.174)$ & 0,0000 \\
Cross-section Chi-square & 201,286115 & 35 & 0,0000 \\
\hline Sumber:
\end{tabular}

Sumber: data diolah, 2020

Uji chow berguna untuk mengetahui apakah model fixed effect lebih sesuai untuk digunakan dibandingkan dengan model common effect (Basuki \& Prawoto, 2016:277). Hasil tertera pada tabel 4. menunjukkan nilai probabilitas cross-section $F$ sebesar 0,0000 , dimana nilainya lebih rendah dari 0,05 , maka dapat diputuskan bahwa $\mathrm{H}_{0}$ ditolak. Hasil tersebut dapat diputuskan bahwa penggunan model fixed effect lebih sesuai dibandingkan penggunaan model common effect.

Tabel 5.

\section{Hasil Uji Hausman}


Uji Hausman bertujuan untuk mengetahui apakah penggunaan model fixed effect lebih sesuai dibandingkan dengan model random effect (Basuki \& Prawoto, 2016:277). Hasil uji hausman yang tertera pada tabel 5. menunjukkan bahwa nilai probabilitas cross-section random sebesar 0,0011 yang mana nilainya kurang dari 0,05, maka dapat diputuskan bahwa $\mathrm{H}_{0}$ ditolak atau penggunan model fixed effect lebih sesuai dibandingkan dengan penggunaan model random effect. Uji lagrange multiple tidak diperlukan karena hasil dari uji chow dan uji hausman membuktikan hal yang sama, yaitu model fixed effect lebih sesuai untuk digunakan. Hasil dari uji regresi data panel yang menggunakan model fixed effect disajikan pada tabel 6 .

Tabel 6.

Hasil Uji Regresi Data Panel dengan Menggunakan Model fixed effect

\begin{tabular}{ccccc}
\hline Variabel & Koefisien & Std. Error & t-Statistik & Prob. \\
C & 43,70672 & 11,92233 & 3,665955 & 0,0003 \\
PROF & 0,385630 & 0,768731 & 0,501645 & 0,6166 \\
GROWTH & $-0,533173$ & 0,255710 & $-2,085074$ & 0,0385 \\
SIZE & $-1,450804$ & 0,408600 & $-3,550675$ & 0,0005 \\
SA & 0,579579 & 0,782551 & 0,740628 & 0,4599 \\
NDTS & $-3,538587$ & 5,251925 & $-0,673770$ & 0,5014 \\
RISK & $-0,000618$ & 0,001275 & $-0,484867$ & 0,6284 \\
\hline R-squared & 0,633076 & Mean dependent variable & 1,525474 \\
Adjusted R-squared & 0,546617 & S.D. dependent variable & 2,375609 \\
S.E. of regression & 1,599587 & Akaike info criterion & & 3,950033 \\
Sum squared resid & 445,2098 & Schwarz criterion & & 4,606337 \\
Log likelihood & $-384,6036$ & Hannan-Quinn criter. & & 4,215182 \\
F-statistic & 7,322256 & Durbin-Watson stat & & \\
Prob(F-statistic) & 0,000000 & & & \\
\hline Sumber: & & & & \\
\hline
\end{tabular}

Sumber: data diolah, 2020 
Pengujian hipotesis yang dilakukan terdiri atas tiga jenis, yaitu analisis koefisien determinasi, uji F, dan uji t. Hasil dari pengujian tersebut disajikan pada tabel 6. Menurut Ghozali \& Ratmono (2017:55-56), koefisien determinasi (Rsquared) berguna untuk mengestimasi seberapa besar kemampuan seluruh variabel independen dalam menjelaskan variasi variabel dependen. Nilai yang dianalisis dalam uji ini adalah nilai Adjusted $R$-squared karena nilainya lebih stabil dibandingkan dengan nilai $R$-squared (Basuki \& Prawoto, 2016:51). Pada penelitian ini Adjusted R-squared memiliki nilai 0,546617 atau 54,6617\%. Nilai tersebut menunjukkan bahwa keenam variabel independen yang terdiri dari Profitabilitas (PROF), Pertumbuhan Perusahaan (GROWTH), Ukuran Perusahaan (SIZE), Struktur Aset (SA), Non-Debt Tax Shield (NDTS), dan Risiko Bisnis (RISK) mampu menjelaskan variabel independen yaitu Struktur Modal (CS) sebesar 0,546617 atau $54,6617 \%$, sedangkan $45,3383 \%$ diterangkan oleh variabel lain diluar penelitian.

Uji $\mathrm{F}$ menunjukkan apakah variabel independen memengaruhi variabel dependen secara simultan atau tidak (Ghozali \& Ratmono, 2017:56). Variabel independen dinyatakan memengaruhi variabel dependen secara simultan jika hasil Prob(F-statistic) lebih rendah dari 0,05. Hasil uji yang tertera pada tabel 6 . memperlihatkan bahwa hasil prob(F-statistic)nya adalah 0,000000 dimana lebih rendah dari 0,05. Hasil tersebut menunjukkan bahwa Profitabilitas (PROF), Pertumbuhan Perusahaan (GROWTH), Ukuran Perusahaan (SIZE), Struktur Aset (SA), Non-Debt Tax Shield (NDTS), dan Risiko Bisnis (RISK) secara bersamasama memengaruhi Struktur Modal (CS). 
Uji t merupakan uji yang mengukur seberapa besar masing-masing variabel independen dapat memengaruhi variabel dependen dengan asumsi bahwa variabel independen lainnya konstan (Ghozali \& Ratmono, 2017:57-58). Suatu variabel independen dinyatakan memengaruhi variabel dependen apabila probabilitas variabel independen lebih rendah dari 0,05. Nilai probabilitas variabel Profitabilitas (PROF), Pertumbuhan Perusahaan (GROWTH), Ukuran Perusahaan (SIZE), Struktur Aset (SA), Non-Debt Tax Shield (NDTS), dan Risiko Bisnis (RISK) disajikan pada tabel 7.

Variabel profitabilitas (PROF) memiliki nilai probabilitas sebesar 0,6166 di mana nilainya diatas 0,05 . Nilai koefisien yang dimilikinya sebesar 0,385630 . Hasil tersebut menandakan bahwa variabel profitabilitas tidak memengaruhi variabel struktur modal, maka $H_{1}$ ditolak. Hasil penelitian tidak sesuai dengan teori trade-off maupun teori pecking order. Nilai rata-rata profitabilitas yang rendah yaitu 0,003993 menandakan rendahnya kemampuan perusahaan dalam menghasilkan laba selama enam tahun terakhir. Hal tersebut mengakibatkan manajer keuangan tidak menjadikan profitabilitas sebagai pertimbangan dalam proses pembentukan struktur modal. Alasan lain yang dapat menyebabkan tidak berpengaruhnya profitabilitas terhadap struktur modal yaitu karena penetapan bentuk struktur modal pada perusahaan didasari oleh perhitungan besar return dan biaya modal yang timbul akibat dari penggunaan utang untuk membiayai operasional perusahaan (Widayanti et al., 2016). Peneliti yang menemukan hubungan serupa adalah Widayanti et al. (2016). 
Nilai probabilitas variabel pertumbuhan perusahaan (GROWTH) adalah 0,0385 di mana nilainya lebih rendah dari 0,05 . Nilai koefisien yang dimiliki adalah $-0,533173$. Hasil tersebut menandakan bahwa variabel pertumbuhan perusahaan memengaruhi variabel struktur modal dengan arah negatif, maka $H_{2}$ ditolak. Hasil penelitian tidak sesuai dengan teori trade-off, tetapi sesuai dengan teori pecking order. Perusahaan yang tingkat pertumbuhan penjualannya tinggi akan menghasilkan keuntungan yang lebih tinggi. Berdasarkan teori pecking order, perusahaan yang menghasilkan laba tinggi akan lebih banyak menggunakan sumber pembiayaan dari laba ditahan dibandingkan menggunakan utang untuk membiayai kegiatannya. Pemakaian lebih banyak dana yang bersumber dari laba ditahan akan mengakibatkan turunnya pemakaian utang. Hasil penelitian serupa ditemukan oleh Dewiningrat \& Mustanda (2018), Alipour et al. (2015), dan Chadha \& Sharma, (2015).

Nilai probabilitas variabel ukuran perusahaan (SIZE) adalah 0,0005 di mana nilainya lebih rendah dari 0,05 , sedangkan nilai koefisiennya adalah $-1,450804$. Hasil penelitian menandakan bahwa variabel ukuran perusahaan memengaruhi variabel struktur modal dengan arah negatif, maka $H_{3}$ ditolak. Hasil penelitian tidak sesuai dengan teori trade-off, tetapi sesuai dengan teori pecking order. Perusahaan berukuran besar penggunaan utangnya cenderung rendah karena telah memiliki aset yang melimpah. Kepemilikan aset yang melimpah berpotensi untuk menghasilkan keuntungan yang tinggi sehingga perusahaan akan mempunyai dana internal yang dapat digunakan untuk membiayai keperluan operasional maupun investasinya (Dewi et al., 2017). Sesuai dengan teori pecking order, jumlah aset yang besar dapat 
digunakan untuk mendanai aktivitas perusahaan seperti membayar utang dan mengembangkan berbagai produk baru (Fahmi, 2018:194). Pemakaian aset sebagai sumber pendanaan aktivitas perusahaan akan menurunkan penggunaan utang, karena kebutuhan dananya telah dipenuhi oleh aset yang dimiliki. Hasil penelitian yang serupa pun ditemukan oleh Kristanti \& Rahayu (2018), Dewi et al. (2017), Acaravci (2015), Alipour et al. (2015), dan Chadha \& Sharma (2015).

Nilai probabilitas yang dimiliki variabel struktur aset (SA) adalah 0,4599 di mana lebih tinggi dari 0,05. Nilai koefisiennya adalah 0,579579. Hasil tersebut menandakan bahwa variabel struktur aset tidak memengaruhi variabel struktur modal, maka $H_{4}$ ditolak. Hasil penelitian tidak sesuai dengan teori trade-off maupun teori pecking order. Panjangnya umur ekonomis dari aset tetap menyebabkan perusahaan tidak membutuhkan banyak dana untuk membiayai kebutuhan aset pada setiap periodenya. Beberapa aset tetap yang berasal dari sewa pun tidak dapat dijadikan sebagai agunan dari utang yang akan diambil. Kondisi tersebut menyebabkan manajer keuangan kurang mempertimbangkan nilai struktur aset dalam proses pembentukan struktur modal. Alasan lain yang menyebabkan struktur aset tidak memengaruhi struktur modal adalah adanya kemungkinan bahwa sumber pembiayaan struktur aset perusahaan adalah menggunakan dana yang bersumber dari modal sendiri sehingga tidak memengaruhi besarnya tingkat utang perusahaan. Hubungan serupa pun ditemukan oleh Dewi et al. (2017) dan Sumani (2015).

Nilai probabilitas variabel non-debt tax shield (NDTS) adalah 0,5014 di mana nilainya lebih tinggi dari 0,05. Nilai koefisien yang dimiliki adalah -3,538587. 
Hasil penelitian menandakan bahwa variabel non-debt tax shield tidak memengaruhi variabel struktur modal, maka $H_{5}$ ditolak. Hasil penelitian tidak sesuai dengan teori trade-off ataupun teori pecking order. Nilai rata-rata non-debt tax shield yang rendah mengakibatkan jumlah tambahan dana internal yang berasal dari nilai depresiasi rendah. Kondisi tersebut mengakibatkan pihak manajemen perusahaan kurang mempertimbangkan tingkat non-debt tax shield dalam proses pembentukan struktur modal. Tambahan dana yang berasal dari nilai depresiasi juga bukan merupakan dana nyata, sehingga tidak dapat membiayai operasional perusahaan secara langsung. Peneliti yang menemukan hubungan serupa adalah Pratheepan \& Banda (2016) dan Acaravci (2015).

Nilai probabilitas variabel risiko bisnis (RISK) adalah 0,6284 di mana lebih tinggi dari 0,05 dan nilai koefisien yang dimiliki adalah -0,000618. Hasil tersebut menandakan bahwa variabel risiko bisnis tidak memengaruhi variabel struktur modal, maka $H_{6}$ ditolak. Nilai rata-rata risiko bisnis yang rendah akan mengakibatkan manajer keuangan kurang mempertimbangkan tingkat risiko bisnis dalam proses penentuan tingkat utang yang akan diambil (Sawitri \& Lestari, 2015). Data variabel risiko bisnis yang sangat bervariasi juga menunjukkan bahwa tingkat risiko bisnis sektor infrastruktur, utilitas, dan transportasi sangat berbeda pada setiap perusahaannya, kondisi tersebut menyebabkan variabel risiko bisnis tidak dapat memprediksi besarnya struktur modal pada sektor ini. Hasil penelitian yang sama pun ditemukan oleh Dewi et al. (2017), Kaliman \& Wibowo (2017), dan Sawitri \& Lestari (2015). 


\section{SIMPULAN DAN SARAN}

Menurut hasil analisa dan pembahasan penelitian, maka dapat diperoleh beberapa kesimpulan. Pertama, pertumbuhan perusahaan dan ukuran perusahaan masing-masing secara negatif signifikan memengaruhi struktur modal. Kedua, profitabilitas, struktur aset, non-debt tax shield, dan risiko bisnis masing-masing tidak memengaruhi struktur modal. Ketiga, ditemukan beberapa determinan struktur modal, yaitu pertumbuhan perusahaan dan ukuran perusahaan.

Saran yang dapat diberikan sesuai dengan kesimpulan yang telah diuraikan sebelumnya adalah pertama, pihak investor disarankan untuk memerhatikan bentuk struktur modal dan faktor-faktor yang memengaruhinya, yaitu pertumbuhan perusahaan dan ukuran perusahaan agar dapat menghasilkan keuntungan yang maksimal. Kedua, pihak manajemen perusahaan sebaiknya mempertimbangkan tingkat pertumbuhan perusahaan dan ukuran perusahaan dalam proses pembentukan struktur modal yang optimal. Ketiga, para peneliti berikutnya disarankan untuk menambah atau mengganti variabel independen yang diduga akan memengaruhi struktur modal, menambahkan periode penelitian agar dapat memperkuat hasil penelitian, dan mengganti objek penelitian karena bentuk struktur modal pada setiap sektor atau perusahaan berbeda-beda.

\section{REFERENSI}

Acaravci, S. K. (2015). The Determinants of Capital Structure: Evidence from the Turkish Manufacturing Sector. International Journal of Economics and Financial Issues, 5(1), 158-171.

Alipour, M., Mohammadi, M. F. S., \& Derakhshan, H. (2015). Determinants of capital structure: An empirical study of firms in Iran. International Journal of 
Law and Management, 57(1), 53-83.

Alnajjar, M. I. M. (2015). Business Risk Impact on Capital Structure : A Case of Jordan Industrial Sector. Global Journal of Management and Businesss Reseach: C Finance, 15(1), 1-7.

Antoni, Chandra, C., \& Susanti, F. (2016). Faktor faktor yang Mempengaruhi struktur Modal Perusahaan Manufaktur di Bursa Efek Indonesia. Jurnal Benefita, 1(2), 119-128.

Basuki, A. T., \& Prawoto, N. (2016). Analisis Regresi dalam Penelitian Ekonomi \& Bisnis: Dilengkapi Aplikasi SPSS \& Eviews (1st ed.). Jakarta: Rajawali Pers.

Chadha, S., \& Sharma, A. K. (2015). Determinants of capital structure: an empirical evaluation from India. Journal of Advances in Management Research, 12(1), 3-14.

Dewi, P. A. G. K., Wiksuana, I. G. B., \& Rahyuda, H. (2017). Variabel-Variabel Penentu Struktur Modal Perusahaan Non Keuangan Di Bursa Efek Indonesia. Matrik: Jurnal Manajemen, Strategi Bisnis Dan Kewirausahaan, 11(1), 92104.

Dewiningrat, A. I., \& Mustanda, I. K. (2018). Pengaruh Likuiditas, Profitabilitas, Pertumbuhan Penjualan, dan Struktur Aset terhadap Struktur Modal. E-Jurnal Manajemen Unud, 7(7), 3471-3501.

Fahmi, I. (2018). Pengantar Manajemen Keuangan Teori dan Soal Jawab. Bandung: ALFABETA.

Ghozali, I., \& Ratmono, D. (2017). Analisis Multivariat dan Ekonometrika Teori, Konsep, dan Aplikasi dengan Eviews 10 (2nd ed.). Semarang: Badan Penerbit Universitas Diponegoro.

Hery. (2016). Analisis Laporan Keuangan Integrated and Comprehensive Edition. Jakarta: Grasindo.

Kaliman, R., \& Wibowo, S. (2017). Pengaruh Ukuran Perusahaan, Risiko Bisnis, Growth ,Profitabilitas , Likuiditas, Dan Sales Growth Terhadap Struktur Modal Pada sektor Farmasi Yang Terdaftar Di Bei. Jurnal Bisnis Dan Akuntansi, 19(3), 185-190.

Krisnanda, P. H., \& Wiksuana, I. G. B. (2015). Pengaruh Ukuran Perusahaan, Pertumbuhan Penjualan, dan Non-Debt Tax Shield Terhadap Struktur Modal pada Perusahaan Telekomunikasi di Bursa Efek Indonesia. E-Jurnal Manajemen Unud, 4(5), 1434-1451.

Kristanti, F. T., \& Iswandi. (2019). The differences of company's performance from CEO diversity. Polish Journal of Management Studies, 19(2), 240-249.

Kristanti, F. T., \& Rahayu, S. (2018). Capital Structure and Performance due to Gender Diversity of CEOs in Indonesian Small \& Medium-sized Business. International Journal of Engineering \& Technology, 7(4.38), 920.

Kyissima, K. H., Xue, G. Z., Kossele, T. P. Y., \& Abeid, A. R. (2019). Analysis of capital structure stability of listed firms in China. China Finance Review International.

Mulyawan, S. (2015). Manajemen Keuangan. Bandung: Pustaka Setia.

Musthafa. (2017). Manajemen Keuangan. Yogyakarta: ANDI.

Pratheepan, T., \& Banda, Y. K. W. (2016). The Determinants of Capital Structure: Evidence from Selected Listed Companies in Sri Lanka. International Journal 
of Economics and Finance, 8(2), 94.

Sawitri, N. P. Y. R., \& Lestari, P. V. (2015). Pengaruh Risiko Bisnis, Ukuran Perusahaan Dan Pertumbuhan Penjualan Terhadap Struktur Modal. E-Jurnal Manajemen Unud, 4(5), 1238-1251.

Sofat, R., \& Singh, S. (2017). Determinants of capital structure: an empirical study of manufacturing firms in India. International Journal of Law and Management, 59(6), 1029-1045.

Sulindawati, N. L. G. E., Yuniarta, G. A., \& Purnamawati, I. G. A. (2017). Manajemen Keuangan Sebagai Dasar Pengambilan Keputusan Bisnis (1st ed.). Depok: Rajawali Pers.

Sumani. (2015). Determinan Struktur Modal Dan Nilai Perusahaan Pertambangan Pasca UU Nomor 4 Tahun 2009. EKUITAS (Jurnal Ekonomi Dan Keuangan), 19(1), 23.

Widayanti, L., Triaryati, N., \& Abundanti, N. (2016). Pengaruh Profitabilitas, Tingkat Pertumbuhan Perusahaan, Likuiditas, Dan Pajak Terhadap Struktur Modal Pada Sektor Pariwisata. E-Jurnal Manajemen Unud, 5(6), 3761-3793. 